\title{
Comparative analysis of different doses of coherent light (laser) and non-coherent light (light-emitting diode) on cellular necrosis and apoptosis: a study in vitro
}

\author{
Vanessa dos Santos Silva, Elizângela Márcia de Carvalho Abreu*, Renata Amadei Nicolau, \\ Cristina Pacheco Soares
}

\begin{abstract}
Introduction: Threshold doses of electromagnetic radiation can initiate necrosis and apoptosis in cells. The purpose of this study was to evaluate cellular apoptosis and necrosis immediately $\left(\mathrm{t}_{0}\right)$ and 24 hours $\left(\mathrm{t}_{24}\right)$ after irradiation with different doses of coherent light (laser) or non-coherent light (LED). Methods: CHO-K1 lineage cells were irradiated with laser $(810 \mathrm{~nm})$ or LED $(945 \pm 20 \mathrm{~nm})$, with $24 \mathrm{~mW}$, contact area of $1 \mathrm{~cm}^{2}$ and doses of $10,20,30,40$ and $50 \mathrm{~J} / \mathrm{cm}^{2}$ for $300,660,960,1230$ and $1620 \mathrm{~s}$, respectively, at both wavelengths. Cells were evaluated by fluorescence microscopy, differentiating viable, apoptotic and necrotic cells immediately and 24 hours after irradiation. Results: The number of necrotic cells at $\mathrm{t}_{0}$ was higher in the LED 40 and $50 \mathrm{~J} / \mathrm{cm}^{2}$ groups ( $86 \pm 14$ and $84 \pm 16 \%$ respectively, $\mathrm{p}<0.05)$, than in the 10 and $20 \mathrm{~J} / \mathrm{cm}^{2}$ laser $(5 \pm 2$ and $5 \pm 3 \%, \mathrm{p}<0.05)$ and LED $(5 \pm 3$ and $4 \pm 1 \%, \mathrm{p}<0.05)$ conditions. At $t_{24}$ the LED $40 \mathrm{~J} / \mathrm{cm}^{2}(80 \pm 20 \%, \mathrm{p}<0.05)$ group also showed more necrosis than the control and lower dose groups (laser 10, 20, and $30 \mathrm{~J} / \mathrm{cm}^{2}$ percentage of $6 \pm 4,10 \pm 3$ and $7 \pm 3 \%$, $\mathrm{p}<0.05$; LED 10 and $20 \mathrm{~J} / \mathrm{cm}^{2}$ percentage of $3 \pm 1$ and $\left.17 \pm 10 \%, \mathrm{p}<0.05\right)$. A decrease in apoptotic cells was observed in the laser group with doses of 10,40 , and $50 \mathrm{~J} / \mathrm{cm}^{2}(6 \pm 4,3 \pm 1$ and $1 \pm 1 \%$ respectively, not significant), as well as in the LED $40 \mathrm{~J} / \mathrm{cm}^{2}(2 \pm 2 \%$, not significant) group versus control. The cells had a higher percentage of apoptosis cells in the control group and with laser doses of 10 and $30 \mathrm{~J} / \mathrm{cm}^{2}$ (percentage of $20 \pm 1$ and $20 \pm 4 \%$, not significant), while only the LED $40 \mathrm{~J} / \mathrm{cm}^{2}(10 \pm 10 \%$, not significant) had a lower percentage compared the control group. Conclusion: Laser or LED stimulation promoted an increase in cell necrosis in a high energy density condition as characterized in a dose-dependent inhibition therapy. Laser or LED infrared irradiation in low doses (up to $20 \mathrm{~J} / \mathrm{cm}^{2}$ ) reduced the percentage of apoptosis in CHO-K1 cells, while high doses $\left(30 \mathrm{~J} / \mathrm{cm}^{2}\right)$ elevated apoptosis.
\end{abstract}

Keywords: Culture cells, Laser, LED, Necrosis, Apoptosis.

\section{Introduction}

Necrosis and apoptosis, the major processes of cell death, may be triggered by various stimuli. Specific alterations in the cell compartment levels during cell death can be identified and measured. Mechanisms of cellular death can be initiated by diverse stimuli, including radiation (Hawkins and Abrahamse, 2005; Huang et al., 2011).

The effects of low level laser therapy (LLLT) and LED therapy (LEDT) at the cellular and molecular levels have been demonstrated in many studies, which showed that irradiation by laser or LED is absorbed by mitochondrial chromophores, including cytochrome c oxidase (Chaves et al., 2014). Irradiation affects the mitochondrial respiratory chain by changing the electrical power of cellular membranes and, consequently, the selective permeability of sodium, potassium, and calcium ions or through increased

*e-mail: eliz_nasa@yahoo.com.br

Received: 15 June 2015 / Accepted: 23 January 2017 activity of enzymes, such as cytochrome c oxidase and ATP syntase (Koutná et al., 2003; Magrini et al., 2012).

It is known that the mitochondria, a fundamental organelle for maintaining vital cellular functions, also plays a key role in cell death through the regulation of cytochromes (Lev-Tov et al., 2013a, b), intracellular $\mathrm{Ca}^{2+}$ concentration (Rimessi et al., 2008), reactive oxygen species (ROS) (Huang et al., 2011; Sun et al., 2010; Wu et al., 2009), transmembrane mitochondrial potential (Belletti et al., 2015; Wu et al., 2009), mitochondrial transition pores by caspases or ATP depletion (Wu et al., 2009), changes in the redox state metabolism (Belletti et al., 2015) and cyclosporine A-sensitive mitochondrial permeability transition (Wu et al., 2009).

It has been reported that LED and laser radiation produce similar effects in therapeutic applications 
(Chaves et al., 2014; Lev-Tov et al., 2013a; Park and Hong, 2015). LED radiation is clinically advantageous for several reasons, including the ability to irradiate a larger area in a short time (Park and Hong, 2015) safety, less painful, and superior portability which allow for patient use at home, with minimal side effects (Lev-Tov et al., 2013a).

LLLT typically involves a light application in the red or near infrared spectrum to promote photostimulation and photoinhibition (Lev-Tov et al., 2013b; Magrini et al., 2012). Studies report similar results for both types of wavelengths, and a high creep promoted the inhibition in proliferation of human skin fibroblasts in vitro (Lev-Tov et al., 2013a, b).

The degree to which light can induce cell death, is still controversial. No definite or proposed doses have been outlined to establish a therapeutic window that can be used for LLLT or LEDT. Therefore, the present study evaluated different doses of coherent (laser) and non-coherent (LED) infrared lights and their ability to induce necrosis and apoptosis.

It is believed that cellular irradiation with high doses of low energy light can promote bioinhibition, while low doses can promote biostimulation.

\section{Methods}

\section{Cellular culture}

The Chinese hamster ovary cell line CHO-K1 was used and was maintained in an HAM F-12 medium supplemented with $10 \%$ fetal bovine serum. Cellular growth was observed using an Olympus CK4 inverted microscope. After forming a confluent monolayer, cell were trypsinized and plated in 24 well culture plates (TPP) containing sterile glass slide ant a density of $5 \times 10^{5}$ cells per well. The total volume of the cell culture media was $200 \mu \mathrm{L}$ per well.

\section{Irradiation}

Before the irradiation procedure, the laser $(810 \mathrm{~nm}$, PHYSIOLASER Olympic ${ }^{\mathrm{TM}}$ - RJ Laser, Germany) and LED ( $945 \pm 20 \mathrm{~nm}$, prototype) equipment were subjected to an assessment of power measurement (Melles Griot-Broadband Power / Energy - Meter 13PE M001) using a spot size of the $0.78 \mathrm{~cm}^{2}$, for both wavelengths. The acrylic plaques and glass slide filtered $20 \%$ of the incident power $(30 \mathrm{~mW})$. The cultures were initially irradiated, in triplicate, with the light source directly in contact with the acrylic under the glass coverslip $\left(0.78 \mathrm{~cm}^{2}\right)$. The cells were irradiated with laser or LED, both irradiation protocols with $24 \mathrm{~mW}$ power. Different doses were used (Table 1), these parameters were chosen because they are commonly used for therapeutic applications
(Belletti et al., 2015). Each dose was administered in triplicate and analysis immediately and 24 hours after irradiation.

The CHO-K1 is a monolayer culture, thus the power enabled the light to extend beyond the acrylic glass coverslip, and the cells received a homogeneous level of radiation. Cells were irradiated in alternate wells to avoid interfering with adjacent wells (Figure 1). All cultures were maintained at room temperature for 30 minutes during control or irradiation treatment. During this time the cultures of the laser and LED groups were irradiated, and the control culture received placebo irradiation.

\section{Fluorescence microscopy}

For fluorescence microscopy acridine orange and ethidium bromide (1:1) were used to morphologically differentiate cellular necrosis and apoptosis. The introduction of acridine orange into DNA produces a green colour, while ethidium bromide only penetrates into dead cells, colouring them red (McGahon et al., 1995; Poersch et al., 2007).

In this experiment, $1 \mu \mathrm{L}$ of acridine orange/ethidium bromide solution was diluted into $25 \mu \mathrm{L}$, which was

Table 1. Parameters of the phototherapy.

\begin{tabular}{ccc}
\hline $\begin{array}{c}\text { Energy Density } \\
\left(\mathbf{J} / \mathbf{c m}^{\mathbf{2}}\right)\end{array}$ & Energy $(\mathbf{J})$ & $\begin{array}{c}\text { Time } \\
\text { (seconds) }\end{array}$ \\
\hline 10 & 7.20 & 300 \\
20 & 15.84 & 660 \\
30 & 43.20 & 960 \\
40 & 29.52 & 1230 \\
50 & 38.88 & 1620 \\
\hline
\end{tabular}

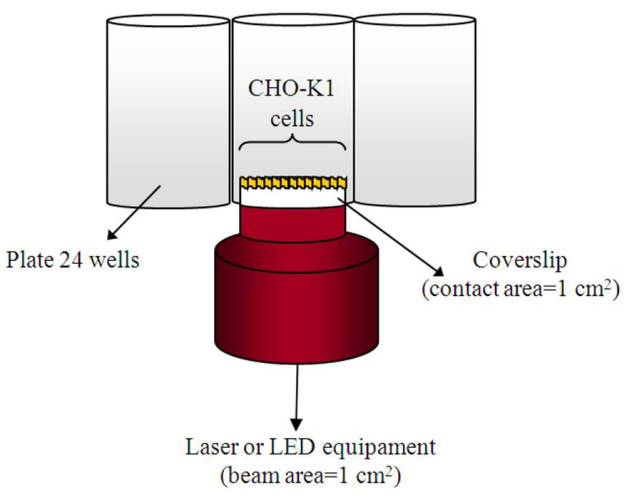

Figure 1. Diagram of the irradiation of wells with microscope glass coverslips. The energy density calculation for each well was performed using the relation of energy and irradiated area. Equipment was placed in contact with the wells during irradiation. The light reached the entire exposure-area of the glass coverslip in the irradiated well Laser and LED equipment as well as the plaques were stabilized during irradiation. The light distribution was uniform at the surface of cells, based on measurements performed before the experiments 
added to each well. Immediately after staining, the glass coverslip was removed and examined by fluorescence microscopy analysis using Leica fluorescence microscope equipped with a $560 \mathrm{~nm}$ excitation filter and a $590 \mathrm{~nm}$ emission filter. The percentage of apoptotic and necrotic cells were determined based on nuclear morphology and cytoplasmic staining. Approximately 400 cells were stained and counted for each sample. The glass slides were photographed under a 40x objective, using a Leica MPS-30 camera (Jeon et al., 2002; Ribble et al., 2005).

\section{Statistical analysis}

The calculation for determining the percentage of cells undergoing apoptosis and necrosis was carried out as follows (Equation 1):

Necrosis or apoptosis $(\%)=\left[\begin{array}{l}n \text { cells undergoing } \\ n \text { ecrosis or apoptosis } \\ n \text { cells counted }\end{array}\right] \times 100$
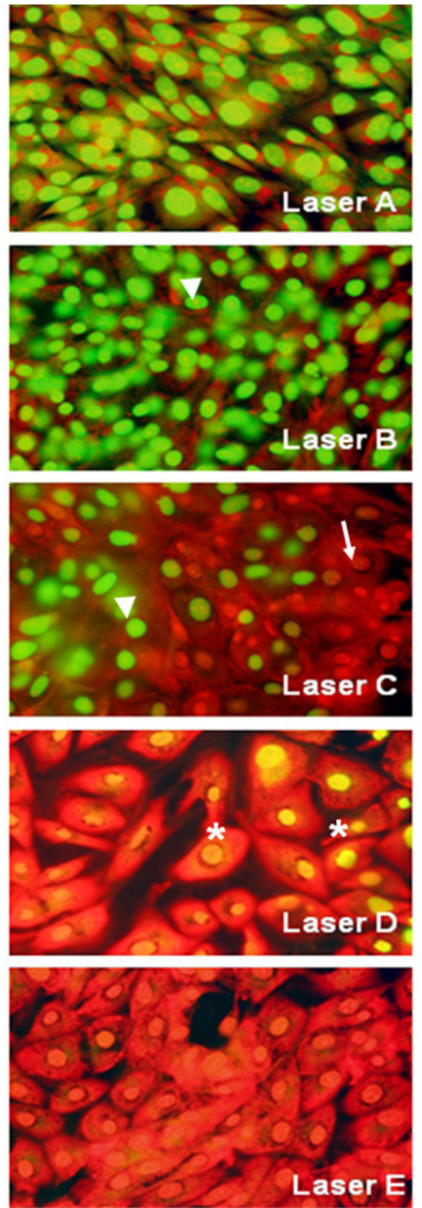

The data are presented as the means with standard deviations. Statistical analysis was carried out using GraphPad Instat 2.05a. An One-way Analysis of Variance (ANOVA) with Tukey-Kramer post-test was used to determine if there was a significant difference between groups, considering a significance level of $5 \%(\mathrm{p}<0.05)$.

\section{Results}

\section{Necrotic and apoptotic cells immediately after irradiation}

The induction of cell death in cells immediately after infrared irradiation can be observed in Figure 2.

The analysis performed after irradiation showed that the percentage of necrotic cells in the cultures exposed to the 10 and $20 \mathrm{~J} / \mathrm{cm}^{2}$ doses was lower than in the control group, which means higher doses resulted in an increase of necrotic cells. Necrosis, however, occurred most dramatically in cells irradiated by LED.
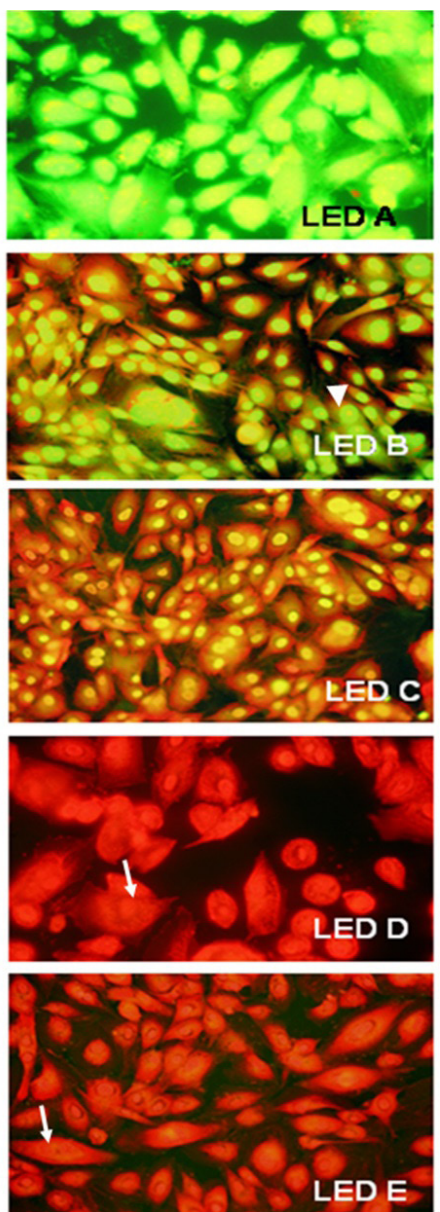

Figure 2. Cellular morphology immediately after the irradiation of cells with different laser or LED energy densities. (A) $10 \mathrm{~J} / \mathrm{cm}^{2}$; (B) $20 \mathrm{~J} / \mathrm{cm}^{2}$; (C) $30 \mathrm{~J} / \mathrm{cm}^{2}$; (D) $40 \mathrm{~J} / \mathrm{cm}^{2}$; and (E) $50 \mathrm{~J} / \mathrm{cm}^{2}$. Fluorescence images of cells labelled by Ethidium Bromide and Acridine Orange taken using a 40x objective. Representative normal cells (arrowhead), necrotic cells (arrow), and apoptotic cells (asterisk) are shown. 
The percentage of necrotic cells, when evaluated immediately after irradiation, was statistically higher $(\mathrm{p}<0.05)$ for the LED group at $40 \mathrm{~J} / \mathrm{cm}^{2}$ compared to the control group and the laser group at $40 \mathrm{~J} / \mathrm{cm}^{2}$. Furthermore the LED group at $50 \mathrm{~J} / \mathrm{cm}^{2}$ was significantly higher $(\mathrm{p}<0.05)$ in relation to the control group and laser group at $40 \mathrm{~J} / \mathrm{cm}^{2}$. The percentage of necrotic cells, evaluated immediately after irradiation was statistically significant $(\mathrm{p}<0.01)$ for the LED group at $40 \mathrm{~J} / \mathrm{cm}^{2}$ compared to the laser groups at 10 and $20 \mathrm{~J} / \mathrm{cm}^{2}$ and the, LED groups at 10 and $20 \mathrm{~J} / \mathrm{cm}^{2}$. The LED group exposed to $50 \mathrm{~J} / \mathrm{cm}^{2}$ displayed a significant difference $(\mathrm{p}<0.01)$ compared to the laser exposed groups at 10 and $20 \mathrm{~J} / \mathrm{cm}^{2}$ and the, LED groups to 10 and $20 \mathrm{~J} / \mathrm{cm}^{2}$ (Table 2).

Our results demonstrated that cultures that were immediately analyzed following irradiation displayed a decrease in the percentage of apoptotic cells in the laser groups with doses at 10,40 , and $50 \mathrm{~J} / \mathrm{cm}^{2}$ compared to the control group. A reduction in the percentage of apoptotic cells was noticeable after using LED irradiation at doses of $40 \mathrm{~J} / \mathrm{cm}^{2}$. LED irradiation at $30 \mathrm{~J} / \mathrm{cm}^{2}$ increased the percentage of apoptotic cells in relation to the other groups (Table 2).

\section{Necrotic and apoptotic cells 24 hours after irradiation}

Cellular morphology was observed 24 hours after irradiation with laser or infrared LED (Figure 3).

The percentage of necrotic cells 24 hours after irradiation was higher in cells treated with $20 \mathrm{~J} / \mathrm{cm}^{2}$ LED irradiation compared to the control group and greater than in the cells treated with $40 \mathrm{~J} / \mathrm{cm}^{2}$ LED $(p<0.05)$. Cell irradiated with laser doses of $40 \mathrm{~J} / \mathrm{cm}^{2}$ and above exhibited higher percentages of necrotic cells than the control group. The average percentage of necrotic cells 24 hours after irradiation was statistically significant $(\mathrm{p}<0.05)$ for the $40 \mathrm{~J} / \mathrm{cm}^{2}$ LED group in relation to control group, the laser groups at 20 and $30 \mathrm{~J} / \mathrm{cm}^{2}$, and the LED group at $20 \mathrm{~J} / \mathrm{cm}^{2}$. There was a $(p<0.01)$ statistically significant difference when comparing cells treated with $40 \mathrm{~J} / \mathrm{cm}^{2}$ LED to cells treated with 10 or $30 \mathrm{~J} / \mathrm{cm}^{2}$ laser, or $10 \mathrm{~J} / \mathrm{cm}^{2} \mathrm{LED}$. Cells treated with $50 \mathrm{~J} / \mathrm{cm}^{2}$ laser irradiation exhibited statistically significant differences in cell death compared to cells treated with 10 or $30 \mathrm{~J} / \mathrm{cm}^{2}$ laser, or $10 \mathrm{~J} / \mathrm{cm}^{2}$ LED. Cells had higher rates of apoptosis when treated with 10 and $30 \mathrm{~J} / \mathrm{cm}^{2}$ laser irradiation compared to the control group 24 after hours of irradiation. In the group irradiated by LED, the percentage of apoptotic cells remained lower than the control when the energy density was $40 \mathrm{~J} / \mathrm{cm}^{2}$. However, these results were not statistically significant (Table 2 and Figure 4).

\section{Discussion}

In this study, we observed increase in necrosis of CHO-K1 cells by fluorescence microscopy following laser and LED irradiation with doses of $30 \mathrm{~J} / \mathrm{cm}^{2}$ or higher. After 24 hours, inhibition of cell death was observed in cells exposed to lower doses of LED $\left(20 \mathrm{~J} / \mathrm{cm}^{2}\right)$ and at $40 \mathrm{~J} / \mathrm{cm}^{2}$ of laser irradiation. These results suggested that the cell death that immediately followed irradiation with $30 \mathrm{~J} / \mathrm{cm}^{2}$ may have been compensated by the proliferation of the remaining cells observed after 24 hours. However, this was not observed in the cells treated with $30 \mathrm{~J} / \mathrm{cm}^{2} \mathrm{LED}$. We hypothesize that this discrepancy was due to the absence of the stimulation of intense cellular division that was observed in cells treated with laser at the same dosage.

The inhibitory effect of irradiation on cells may be due to an accumulation of ROS in both laser and LED irradiation (Belletti et al., 2015; Mamalis et al., 2015), due to the intense excitement of mitochondrial activity. ROS accumulation is associated with decreased transmembrane mitochondrial potential, decreased metabolism and changes in gene expression resulting in the disruption of ATP synthesis and cell death (Belletti et al., 2015; Magrini et al., 2012).

Even small changes in ATP level can significantly alter cellular metabolism. A long series of discoveries have demonstrated that ATP is not only an energy currency inside cells but is also a critical signalling molecule that allows cells and tissues to communicate

Table 2. Percentage of necrotic and apoptotic cells immediately $\left(t_{0}\right)$ and 24 hours $\left(t_{24}\right)$ after laser or LED irradiation with different energy densities (from 10 to $50 \mathrm{~J} / \mathrm{cm}^{2}$ ). The data are presented the means and their respective standard deviations.

\begin{tabular}{|c|c|c|c|c|c|c|c|c|c|c|c|c|}
\hline \multirow{3}{*}{ Analysis } & \multirow{3}{*}{ Time } & \multicolumn{11}{|c|}{ Dose $\left(\mathrm{J} / \mathrm{cm}^{2}\right)$} \\
\hline & & \multirow{2}{*}{$\begin{array}{c}0 \\
\text { (control) }\end{array}$} & \multicolumn{2}{|c|}{10} & \multicolumn{2}{|c|}{20} & \multicolumn{2}{|c|}{30} & \multicolumn{2}{|c|}{40} & \multicolumn{2}{|c|}{50} \\
\hline & & & laser & $L E D$ & laser & $L E D$ & laser & $L E D$ & laser & $L E D$ & laser & $L E D$ \\
\hline \multirow{2}{*}{$\begin{array}{l}\text { Necrosis } \\
(\%)\end{array}$} & $\mathbf{t}_{0}$ & $14 \pm 4$ & $5 \pm 2^{\dagger+}$ & $5 \pm 3^{\dagger+}$ & $5 \pm 3^{\dagger *}$ & $4 \pm 1^{\text {斻 }}$ & $28 \pm 12$ & $66 \pm 30$ & $40 \pm 15$ & $86 \pm 14^{* \#}$ & $56 \pm 11$ & $84 \pm 16^{\text {*\# }}$ \\
\hline & $\mathbf{t}_{24}$ & $14 \pm 4$ & $6 \pm 4^{\# \dagger}$ & $3 \pm 1^{\# \uparrow}$ & $10 \pm 3^{\dagger}$ & $17 \pm 10^{* \dagger}$ & $7 \pm 3^{\# \uparrow}$ & $28 \pm 5$ & $48 \pm 16$ & $80 \pm 20^{*}$ & $68 \pm 7$ & $52 \pm 26$ \\
\hline \multirow{2}{*}{$\begin{array}{c}\text { Apoptosis } \\
(\%)\end{array}$} & $\mathbf{t}_{0}$ & $12 \pm 3$ & $6 \pm 4$ & $12 \pm 5$ & $11 \pm 5$ & $12 \pm 2$ & $9 \pm 4$ & $29 \pm 25$ & $3 \pm 1$ & $2 \pm 2$ & $1 \pm 1$ & $9 \pm 9$ \\
\hline & $t_{24}$ & $12 \pm 3$ & $20 \pm 1$ & $14 \pm 5$ & $9 \pm 9$ & $18 \pm 8$ & $20 \pm 4$ & $13 \pm 2$ & $2 \pm 1$ & $10 \pm 10$ & $1 \pm 1$ & $42 \pm 27$ \\
\hline
\end{tabular}

${ }^{*} \mathrm{p}<0.05$ vs control; \# $\mathrm{p}<0.05$ vs laser; $¥ \mathrm{p}<0.05$ vs laser $50 \mathrm{~J} / \mathrm{cm} 2 ; \uparrow \mathrm{p}<0.05 \mathrm{vs}$ LED $40 \mathrm{~J} / \mathrm{cm} 2 ; \ddagger \mathrm{p}<0.05 \mathrm{vs} \mathrm{LED} 50 \mathrm{~J} / \mathrm{cm} 2$. 

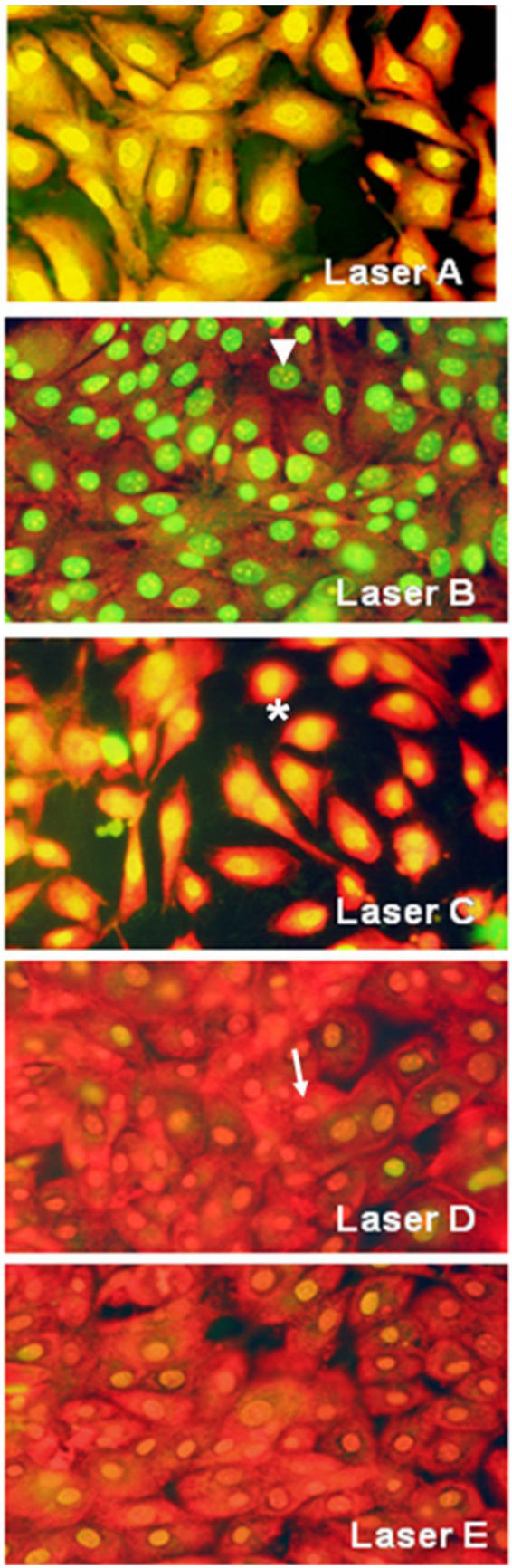
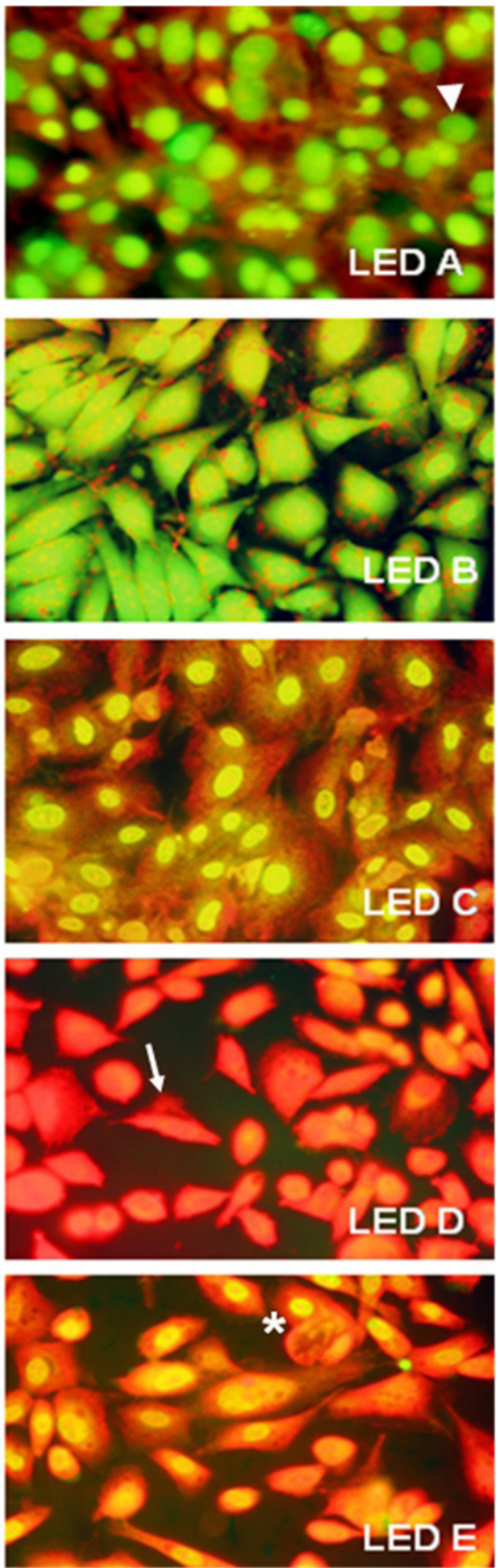

Figure 3. Analysis of cellular morphology 24 hours after irradiation with different energy densities. (A) $10 \mathrm{~J} / \mathrm{cm}^{2}$; (B) $20 \mathrm{~J} / \mathrm{cm}^{2}$; (C) $30 \mathrm{~J} / \mathrm{cm}^{2}$; (D) $40 \mathrm{~J} / \mathrm{cm}^{2}$; and (E) $50 \mathrm{~J} / \mathrm{cm}^{2}$. Fluorescence image of cells labeled by Ethidium Bromide and Acridine Orange. Photos were taken using a 40x objective. Representative normal cells (arrowhead), necrotic cells (arrow), and apoptotic cells (asterisk) are shown.

with one another. Neurons release ATP into muscle, gut, and bladder tissue as a messenger molecule. ATP activation of $\mathrm{P} 2$ receptors (subtypes $\mathrm{P} 2 \mathrm{X}$ and $\mathrm{P} 2 \mathrm{Y}$ ) can produce different cellular effects. When bound by ATP, P2X receptors flux sodium and calcium into the cell, causing intracellular calcium stores to be released. This finding suggests that intracellular calcium concentrations are regulated by extracellular processes, such as the binding of ATP to P2X receptors (Karu, 2010).

Alexandratou et al. (2002) found that the increased formation of ROS combined with increased intracellular $\mathrm{Ca}^{2+}$ and mitochondrial membrane potential are mechanisms involved in necrosis following irradiation. 
A

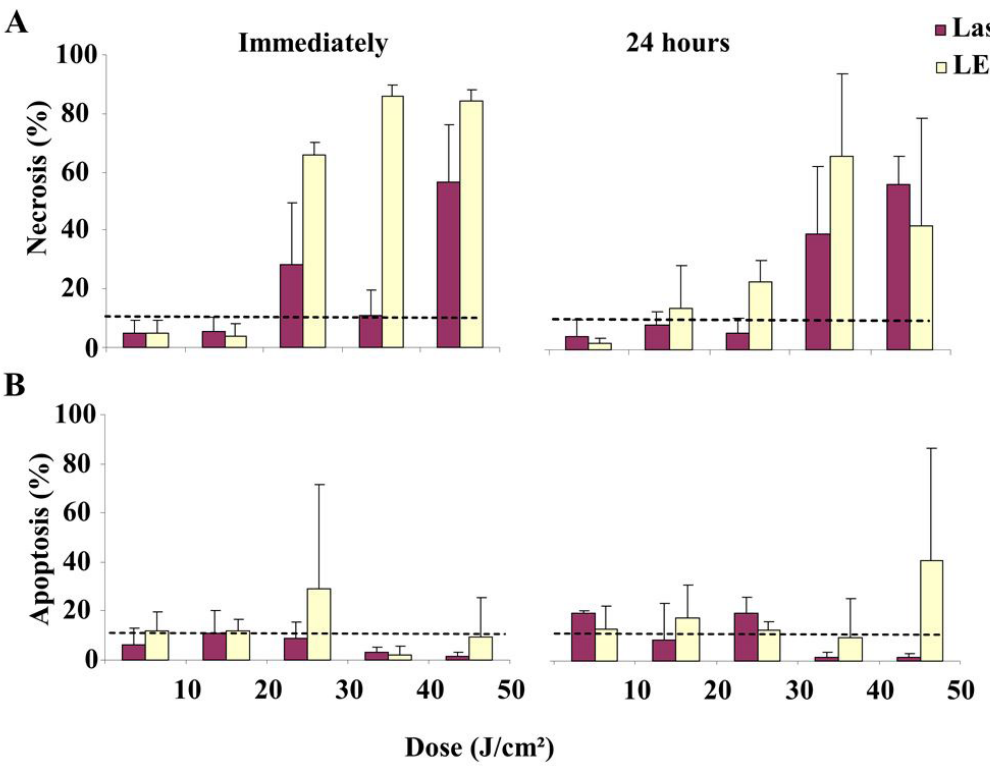

Figure 4. Percentage of necrotic (A) and apoptotic (B) cells immediately and 24 hours after laser or LED irradiation with different energy density (ranging from 10 to $50 \mathrm{~J} / \mathrm{cm}^{2}$ ).

Low doses of irradiation can stimulate increased $\mathrm{Ca}^{2+}$ and induce mitosis increasing cellular proliferation. At higher doses, a higher concentration of $\mathrm{Ca}^{2+}$ is released causing hyperactivity of $\mathrm{Ca}^{2+}$ - ATPase, an enzyme that promotes calcium influx, which exhausts the ATP reserves in the cell (Hawkins and Abrahamse, 2005), and thereby promotes cell death.

Huang et al. (2011) identified a new and important pro-apoptotic signalling pathway that utilized Akt/GSK3 $\beta$ inactivation by High fluence LLLT (HF-LLLT) $\left(120 \mathrm{~J} / \mathrm{cm}^{2}, 633 \mathrm{~nm}\right)$ stimulation. The authors found that the activation of glycogen synthase kinase $3 \beta$ (GSK3 $\beta$ ) by HF-LLLT was due to the inactivation of protein kinase $\mathrm{B}(\mathrm{Akt})$, a widely reported and important upstream negative regulator of GSK3 3 . GSK3b promotes cell apoptosis caused by oxidative stress, DNA damage, endoplasmic reticulum stress and ceramide exposure. In addition, the results showed that cleaved caspase- 3 was detected in all cells treated with HF-LLLT. Moreover the authors indicated the involvement of ROS and Bax activation in the pathway.

Zhang et al. (2009) demonstrated that PKC $\delta$ promotes cell apoptosis in human breast adenocarcinoma cells (MCF-7) caused by HF-LLLT (He-Ne for $10 \mathrm{~min}$ under a fluence of $120 \mathrm{~J} / \mathrm{cm}^{2}$ ), providing new insight into HF-LLLT mechanisms.

Sun et al. (2010) explored the involvement of signal transducer and activator of transcription 3 (Stat3) in the regulation of apoptosis induced by HF-LLLT $(633 \mathrm{~nm})$ in COS-7 cells. HF-LLLT at both 80 and $120 \mathrm{~J} / \mathrm{cm}^{2}$ resulted in nuclear translocation of Stat3, suggesting that Stat 3 could be activated by HF-LLLT. Stat 3 began to translocate to the nucleus at $20 \mathrm{~min}$, reached a peak at $40 \mathrm{~min}$, and then remained unchanged for up to $3 \mathrm{~h}$ after both fluences. Their result indicated that Src (a kinase) played a major role in Stat 3 activation and that activation of the Src-Stat3 pathway could inhibit apoptosis induced by HF-LLLT. In addition, the authors indicated a critical role for ROS in Stat 3 activation. In conclusion, these findings demonstrated that the ROS-Src-Stat3 pathway mediated negative feedback inhibition of apoptosis under HF-LLLT. The authors believed that one of the crosslinks between anti-apoptotic pathways and pro-apoptotic pathways under HF-LLLT was Stat3, through transcriptional upregulation of the Bcl-2 the anti-apoptotic proteins to attenuate Bax activation. Moreover, the expression of surviving, cyclin D1 and c-Myc may also be involved. 
Zhang et al. (2008) also showed the activation of Src by ROS generation induced by HF-LLLT at relatively high laser doses $\left(25\right.$ and $\left.50 \mathrm{~J} / \mathrm{cm}^{2}\right)$.

Many in vitro studies have shown that there is no consensus on dosimetry to promote bioinhibition. Magrini et al. (2012) used a $\mathrm{HeNe}$ laser $(633 \mathrm{~nm})$ for irradiation of malignant breast cells and found that a dose of $5 \mathrm{~J} / \mathrm{cm}^{2}$ promoted bioinhibition with decreased metabolic rate and a dose of $1 \mathrm{~J} / \mathrm{cm}^{2}$ promoted biostimulation. Belletti et al. (2015) used a GaAs laser ( $915 \mathrm{~nm}$, with 5,15 to $45 \mathrm{~J} / \mathrm{cm}^{2}$ ) to irradiate human skin fibroblasts and observed that high doses $\left(15\right.$ and $\left.45 \mathrm{~J} / \mathrm{cm}^{2}\right)$ promoted the reduction of the transmembrane mitochondrial potential. Park and Hong (2015) applied red and white LED (600-650 nm, $0.3 \mathrm{~J} / \mathrm{cm}^{2}$ and $400-750 \mathrm{~nm}$ with $\left.1.26 \mathrm{~J} / \mathrm{cm}^{2}\right)$ in human gingival fibroblasts and observed that both fluencies promoted increased proliferation and migration cells. Lev-Tov et al. (2013a) irradiated human skin fibroblasts with LED at $830 \mathrm{~nm}$ with 80,160 and $320 \mathrm{~J} / \mathrm{cm}^{2}$, and Lev-Tov et al. (2013b) used LED at $633 \mathrm{~nm}$ with 160,320 and $640 \mathrm{~J} / \mathrm{cm}^{2}$. In both studies, it was observed that all fluencies inhibited fibroblast proliferation without altering viability.

Determining the mechanisms of action of phototherapy is important for the clinical application of LLLT and LEDT, especially for dose and wavelength selection. Considering the therapeutic goals of stimulating or inhibiting cells, phototherapy can also be used for cell proliferation in tissue repair or to treat some types of hyperplasia, such as using photodynamic treatment in the absence of photosensitizers. Phototherapy using high fluence represents a new stimulator to trigger cell apoptosis, and could be used widely as a new and low-cost method to induce cellular apoptosis for research and therapy.

This study revealed that the effect of light irradiation on cells is dose-dependent. If the therapeutic goal is to promote cell proliferation or survival, then the preferred irradiation dose should be less than $20 \mathrm{~J} / \mathrm{cm}^{2}$; but, if the goal is inhibition of cells, the dose must be greater than $30 \mathrm{~J} / \mathrm{cm}^{2}$. Based on this principle, phototherapy can also be used for cell proliferation in tissue repair or to treat some types of hyperplasia such as using photodynamic treatment. Phototherapy using high fluence represents a new stimulator to trigger cell apoptosis, and could be used widely as a new and low-cost method to induce apoptosis for research and therapy.

Our study was limited and could have utilized other forms of evaluation, such as confocal microscopy for ROS detection and changes in transmembrane mitochondrial potential (Belletti et al., 2015). Additionally, micro-Fourier transform infrared spectroscopy for metabolic reviews could have provided some benefit (Magrini et al., 2012). In addition, our study was performed in vitro and not in humans.

Laser and LED stimulation promoted increases in necrosis in CHO-K1 cells at high energy densities, characterized as a dose-dependent inhibition therapy. Laser or LED infrared irradiation at low doses (up to $20 \mathrm{~J} / \mathrm{cm}^{2}$ ) reduced the percentage of apoptotic cells, while high doses (at $30 \mathrm{~J} / \mathrm{cm}^{2}$ ) elevated the amount apoptotic cells.

\section{Acknowledgements}

Silva VS and Abreu EMC thank the CAPES/PROSUP (Ministry of Education, Brazil) for the Master's fellowship. The authors thank RJ-LASER REIMERS \& JANSSEN GmbH Medical - Laser - Technology for the grant of transferred equipment (PHYSIOLASER Olympic), and this project has been supported by the following Brazilian agencies: UNIVAP and FAPESP (grant $n^{\circ}$ 2006/06736-5).

\section{References}

Alexandratou E, Yova D, Handris P, Kletsas D, Loukas S. Human fibroblast alterations induced by low power laser irradiation at the single cell level using confocal microscopy. Photochemical \& Photobiological Sciences. 2002; 1(8):54752. PMid:12659495. http://dx.doi.org/10.1039/b110213n.

Belletti S, Uggeri J, Mergoni G, Vescovi P, Merigo E, Fornaini C, Nammour S, Manfredi M, Gatti R. Effects of $915 \mathrm{~nm}$ GaAs diode laser on mitochondria of human dermal fibroblasts: analysis with confocal microscopy. Lasers in Medical Science. 2015; 30(1):375-81. PMid:25351448. http://dx.doi.org/10.1007/s10103-014-1651-z.

Chaves MEA, Araújo AR, Piancastelli ACC, Pinotti M. Effects of low-power light therapy on wound healing: LASER x LED. Anais Brasileiros de Dermatologia. 2014; 89(4):616-23. PMid:25054749. http://dx.doi.org/10.1590/ abd1806-4841.20142519.

Hawkins D, Abrahamse H. Laboratory methods for evaluating the effect of low level laser therapy (LLLT) in wound healing. African Journal of Biomedical Research. 2005; 8:1-14. http://dx.doi.org/10.4314/ajbr.v8i1.35752.

Huang L, Wu S, Xing D. High fluence low-power laser irradiation induces apoptosis via inactivation of Akt/GSK3 $\beta$ signaling pathway. Journal of Cellular Physiology. 2011; 226(3):588-601. PMid:20683916. http://dx.doi.org/10.1002/ jcp. 22367.

Jeon BW, Kim KT, Chang S, Kim HY. Phosphoinositide 3-OH kinase/protein kinase b inhibits apoptotic cell death induced by reactive oxygen species in saccharomyces cerevisiae. Journal of Biochemistry. 2002; 131(5):693-9. PMid:11983076. http://dx.doi.org/10.1093/oxfordjournals. jbchem.a003153. 
Karu TI. Multiple roles of cytochrome C oxidase in mammalian cells under action of red and IR-A radiation. International Union of Biochemistry and Molecular Biology Life. 2010; 62(8):607-10. PMid:20681024. http://dx.doi. org/10.1002/iub.359.

Koutná M, Janisch R, Veselská R. Effects of low-power laser irradiation on cell proliferation. Scripta Medica. 2003; 76(3):163-72.

Lev-Tov H, Brody N, Siegel D, Jagdeo J. Inhibition of fibroblast proliferation in vitro using low-level infrared light-emitting diodes. Dermatologic Surgery. 2013a; 39(3 Pt1):422-5. PMid:23279196. http://dx.doi.org/10.1111/ dsu. 12087.

Lev-Tov H, Mamalis A, Brody N, Siegel D, Jagdeo J. Inhibition of fibroblast proliferation in vitro using red lightemitting diodes. Dermatologic Surgery. 2013b; 39(8):116770. PMid:23590233. http://dx.doi.org/10.1111/dsu.12212.

Magrini TD, Santos NV, Milazzotto MP, Cerchiaro G, Martinho HS. Low-level laser therapy on MCF-7 cells: a micro-Fourier transform infrared spectroscopy study. Journal of Biomedical Optics. 2012; 17(10):101516. PMid:23223992. http://dx.doi.org/10.1117/1.JBO.17.10.101516.

Mamalis A, Garcha M, Jagdeo J. Light emitting diodegenerated blue light modulates fibrosis characteristics: fibroblast proliferation, migration speed, and reactive oxygen species generation. Lasers in Surgery and Medicine. 2015; 47(2):210-5. PMid:25655579. http://dx.doi.org/10.1002/ $1 \mathrm{sm} .22293$.

McGahon AJ, Martin SJ, Bissonnette RP, Mahboubi A, Shi Y, Mogil RJ, Nishioka WK, Green DR. The end of the (cell) line: Methods for the study of apoptosis in vitro. Methods in Cell Biology. 1995; 46:153-84. PMid:7541883. http:// dx.doi.org/10.1016/S0091-679X(08)61929-9.

Park JT, Hong KS. Effect of light-emitting-diode irradiation on the proliferation and migration in human gingival fibroblasts. Tissue Engineering and Regenerative Medicine. 2015; 12(1):37-42. http://dx.doi.org/10.1007/s13770-014-9061-7.
Poersch A, Santos FV, Maciel MAM, Camara JK, Dantas TN, Cólus IMS. Protective effect of DCTN (transdehydrocrotonin) against induction of micronuclei and apoptosis by different mutagenic agents in vitro. Mutation Research. 2007; 629(1):14-23. PMid:17276134. http:// dx.doi.org/10.1016/j.mrgentox.2007.01.001.

Ribble D, Goldstein NB, Norris DA, Shellman YG. A simple technique for quantifying apoptosis in 96-well plates. BMC Biotechnology. 2005; 5(12):1-7. http://dx.doi. org/10.1186/1472-6750-5-12. PMid:15885144.

Rimessi A, Giorgi C, Pinton P, Rizzuto R. The versatility of mitochondrial calcium signals: from stimulation of cell metabolism to induction of cell death. Biochimica et Biophysica Acta. 2008; 1777:808-16. http://dx.doi. org/10.1016/j.bbabio.2008.05.449.

Sun X, Wu S, Xing D. The reactive oxygen species-Src-Stat3 pathway provokes negative feedback inhibition of apoptosis induced by high-fluence low-power laser irradiation. Federation of European Biochemical Societies Journal. 2010; 277(22):4789-802. http://dx.doi.org/10.1111/j.17424658.2010.07884.x. PMid:20977672.

Wu S, Xing D, Gao X, Chen W. High fluence low-power laser irradiation induces mitochondrial permeability transition mediated by reactive oxygen species. Journal of Cellular Physiology. 2009; 218(3):603-11. PMid:19006121. http:// dx.doi.org/10.1002/jcp.21636.

Zhang H, Xing D, Wu S, Sun X. Protein kinase C $\delta$ promotes cell apoptosis induced by high fluence low-power laser irradiation. In: Proceedings of SPIE 7519. 8th International Conference on Photonics and Imaging in Biology and Medicine (PIBM 2009); 2009 Aug 8; Wuhan, China. SPIE; 2009. http://dx.doi.org/10.1117/12.841566.

Zhang J, Xing D, Gao X. Low-power laser irradiation activates Src tyrosine kinase through reactive oxygen species-mediated signalling pathway. Journal of Cellular Physiology. 2008; 217(2):518-28. PMid:18615581. http:// dx.doi.org/10.1002/jcp.21529.

\footnotetext{
Authors

Vanessa dos Santos Silva ${ }^{1}$, Elizângela Márcia de Carvalho Abreu ${ }^{2 *}$, Renata Amadei Nicolau ${ }^{1}$, Cristina Pacheco Soares $^{3}$

${ }^{1}$ Lasertherapy and Photobiology Center, Institute of Research and Development - IP\&D, Universidade do Vale do Paraíba - UNIVAP, São José dos Campos, SP, Brazil.

${ }^{2}$ Sensory Motor Rehabilitation Engineering Laboratory, Institute of Research and Development - IP\&D, Universidade do Vale do Paraíba - UNIVAP, Avenida Shishima Hifumi, 2911, Urbanova, CEP 12244-000, São José dos Campos, SP, Brazil.

${ }^{3}$ Dynamics of Cellular Compartments Laboratory, Institute of Research and Development - IP\&D, Universidade do Vale do Paraíba - UNIVAP, São José dos Campos, SP, Brazil.
} 